\title{
SPECTRUM OF UNNATURAL DEATHS IN PALPA, NEPAL: AUTOPSY BASED STUDY
}

\author{
Atreya $A^{1^{*}}$, Nepal $S^{2}$, Gyawali $P R^{3}$
}

\begin{abstract}
Affiliation
1. Assistant Professor, Department of Forensic Medicine, Lumbini Medical College Teaching Hospital, Palpa, Nepal.

2. Lecturer, Department of Community Medicine, Lumbini Medical College Teaching Hospital, Palpa, Nepal.

3. Medical Superintendent, District Hospital Palpa, Nepal.
\end{abstract}

\section{ARTICLE INFO}

Received : 20 May, 2019

Accepted : 13 August, 2019

Published : 31 August, 2019

(C) Authors retain copyright and grant the journal right of first publication with the work simultaneously licensed under Creative Commons Attribution License CC - BY 4.0 that allows others to share the work with an acknowledgment of the work's authorship and initial publication in this journal.

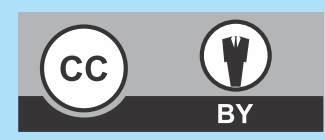

ORA 125

DOI: http://dx.doi.org/10.3126/bjhs.v4i2.25458

* Corresponding Author

Dr. Alok Atreya

Assistant Professor

Department of Forensic Medicine

Lumbini Medical College Teaching Hospital, Palpa, Nepal.

Email ID : alokraj67@hotmail.com

ORCID ID : https://orcid.org/0000-0001-6657-7871

\section{Citation}

Atreya A, Nepal S, Gyawali PR. Spectrum of Unnatural Deaths in Palpa, Nepal: Autopsy Based Study. BJHS 2019;4(2)9: 744 - 749.

\section{ABSTRACT}

\section{Introduction}

Analysis of unnatural death of a community reflects the cause of death and socio-economic strata of that society. Medico-legal autopsies are conducted under the ordinance of legal authority in all cases of unnatural deaths.

\section{Objectives}

The present study is aimed to determine the spectrum of unnatural deaths in Tansen Municipality of Papla district of Province 5, Nepal.

\section{Methodology}

This autopsy based study was conducted during the Nepalese fiscal calendar 2074/75 which includes all the cases autopsied in the mortuary of District Hospital Tansen, Palpa.

\section{Results}

Of total 184 medico-legal autopsies road traffic accidents (RTA) was the leading cause of death ( $n=53,28.8 \%)$ followed by hanging $(n=43,23.41 \%)$ and burn $(n=33,17.9 \%)$. Of the 33 cases of burn 25 were females (13.6\%) and 8 males (4.3\%). There were 13 cases (7.1\%) of obscure autopsy.

\section{Conclusion}

The present study reflected the spectrum of unnatural deaths in Palpa district of province 5, Nepal which revealed RTA as a leading cause of death, followed by hanging. When gender was taken into account it was revealed that more females succumbed to death due to complications of the burn injuries sustained. Unnatural death due to fatal poisoning was least common finding of the present study although poisoning is one of the leading causes of deliberate self-harm globally. Proposal/program of collaboration of District Hospital with other tertiary care centres of Palpa district is the need of the hour which would provide specific, timely and expert approach to range of medicolegal cases.

\section{KEYWORDS}

Accidents, autopsy, hanging, poisoning, unnatural deaths 


\section{INTRODUCTION}

The mortality data is complete and medically important indicator of health in a population. ${ }^{1}$ However, precise statistical data is rare in most of the countries. ${ }^{2}$ The 'Who Counts ?' series published in Lancet states: "Most people in Africa and Asia are born and die without leaving a trace in any legal record or official statistic. Absence of reliable data for births, deaths, and causes of death are at the root of this scandal of invisibility, which renders most of the world's poor as unseen, uncountable, and hence uncounted. ${ }^{\prime 3}$

Medico-legal autopsies are the source of such information in cases of unnatural deaths. In unnatural deaths medico-legal autopsies are conducted under the ordinance of legal authority. ${ }^{4}$ Autopsy examination is usually done to find out the exact cause of death in most cases. Other objectives of conducting autopsies include establishment of identity of the deceased in mass disaster or mutilated bodies, determining the manner of death and also to estimate the time since death. In homicidal cases, autopsy examination provides the evidences to link the crime with the criminal. The present study is aimed to determine the spectrum of unnatural deaths in Tansen Municipality of Palpa district in Province 5 of Nepal.

\section{METHODOLOGY}

Palpa is one of the twelve districts in Province 5, Nepal. This district has two municipalities and eight rural municipalities. Tansen is the largest municipality and also the district head quarters. District hospital at Tansen is the government run hospital which is permitted to conduct medico-legal autopsies.

After approval from the concerned authority this study was conducted during the Nepalese fiscal calendar 2074/75 which lies between 15 June 2017 and 14 June 2018 as per Gregorian calendar. This one year study included all the 184 cases autopsied in the mortuary of District Hospital Tansen. All the relevant data was first noted into the proforma and entered and analyzed using statistical analysis software SPSS version 21 (SPSS. Inc., Chicago).

\section{RESULTS}

In the present study, a total of 184 medico-legal autopsies were performed in the mortuary of District Hospital, Palpa. In the current study road traffic accidents (RTA) was the leading cause of death attributing 53 cases (28.8\%).

There were 43 cases $(23.41 \%)$ of hanging and 9 cases $(4.9 \%)$ of poisoning. In 13 cases (7.1\%) opinion as to cause of death could not be determined (Table 1). During the study period death as a result of burn injuries was evident in 33 cases (17.9\%) of which 25 were females (13.6\%) and 8 were males (4.3\%).

When age of the victims were categorized, it was observed that more deceased belonged to age group of $41-50$ years (19.6\%) followed by the age group of $31-40$ years (17.4\%). Month wise distribution of cases as per gender and age group is depicted in Table 2 and Table 3 respectively.

When age group of the victim was compared with the cause of death (Table 4) it was apparent that most of the victims belonging to the age group of 11-20 years died due to hanging ( $n=12,6.5 \%)$. RTA was more prevalent during the middle age, 38 fatalities (20.7\%) occurring in between 31 to 60 years.

Gender differences were apparent for individual cause of death. Gender wise analysis revealed more males ( $n=37,20.2 \%$ ) succumbed to death in RTAs than the females $(n=16,8.6 \%)$. Overall male preponderance was observed except in cases of burn and poisoning.

\begin{tabular}{|c|c|c|c|}
\hline Cause of death & $\begin{array}{l}\text { Male } \\
\text { N (\%) }\end{array}$ & $\begin{array}{l}\text { Female } \\
\mathrm{N}(\%)\end{array}$ & $\begin{array}{l}\text { Total } \\
\text { N (\%) }\end{array}$ \\
\hline Hanging & $26(14.1)$ & $17(9.3)$ & $43(23.4)$ \\
\hline Drowning & $10(5.5)$ & $5(2.7)$ & $15(8.2)$ \\
\hline Burn & $8(4.3)$ & $25(13.6)$ & $33(17.9)$ \\
\hline Injury (RTA) & $37(20.2)$ & $16(8.6)$ & $53(28.8)$ \\
\hline Injury (other than RTA) & $8(4.3)$ & $4(2.2)$ & $12(6.5)$ \\
\hline Electrocution & $1(0.5)$ & 0 & $1(0.5)$ \\
\hline Poisoning & $3(1.6)$ & $6(3.3)$ & $9(4.9)$ \\
\hline Undetermined & $7(3.8)$ & $6(3.3)$ & $13(7.1)$ \\
\hline Others & $2(1.1)$ & $3(1.6)$ & $5(2.7)$ \\
\hline Total & $102(55.4)$ & $82(44.6)$ & 184(100) \\
\hline
\end{tabular}

Table 2: Month wise distribution of cases $(n=184)$.

$\begin{array}{lll}\text { Month } & \text { Male } & \text { Female } \\ \text { N (\%) } & \text { N (\%) } \\ \text { June } & 14(7.7) & 8(4.3) \\ \text { July } & 6(3.3) & 3(1.6) \\ \text { August } & 10(5.4) & 5(2.7) \\ \text { September } & 15(8.2) & 8(4.3) \\ \text { October } & 11(6.0) & 9(4.9) \\ \text { November } & 5(2.7) & 5(2.7) \\ \text { December } & 9(4.9) & 2(1.1) \\ \text { January } & 3(1.6) & 9(4.9) \\ \text { February } & 4(2.2) & 11(6.0) \\ \text { March } & 7(3.8) & 12(6.5) \\ \text { April } & 6(3.3) & 7(3.8) \\ \text { May } & 12(6.5) & 3(1.6) \\ \text { Total } & 102(55.4) & 82(44.6)\end{array}$




\begin{tabular}{|c|c|c|c|c|c|c|c|c|c|c|}
\hline \multicolumn{11}{|c|}{ Age Group (in years) } \\
\hline Month & $\begin{array}{c}<10 \\
N(\%)\end{array}$ & $\begin{array}{l}11-20 \\
N(\%)\end{array}$ & $\begin{array}{l}21-30 \\
N(\%)\end{array}$ & $\begin{array}{l}31-40 \\
N(\%)\end{array}$ & $\begin{array}{l}41-50 \\
N(\%)\end{array}$ & $\begin{array}{l}51-60 \\
N(\%)\end{array}$ & $\begin{array}{l}61-70 \\
N(\%)\end{array}$ & $\begin{array}{l}71-80 \\
N(\%)\end{array}$ & $\begin{array}{c}>81 \\
N(\%)\end{array}$ & $\begin{array}{l}\text { Total } \\
\text { N (\%) }\end{array}$ \\
\hline June & 0 & $4(2.2)$ & $4(2.2)$ & $2(1.1)$ & $6(3.3)$ & $5(2.7)$ & $1(0.5)$ & 0 & 0 & $22(12.0)$ \\
\hline July & 0 & $2(1.1)$ & 0 & $1(0.5)$ & $2(1.1)$ & $3(1.6)$ & 0 & $1(0.5)$ & 0 & $9(4.9)$ \\
\hline August & $2(1.1)$ & 0 & 0 & $2(1.1)$ & $6(3.3)$ & $1(0.5)$ & $1(0.5)$ & $2(1.1)$ & $1(0.5)$ & $15(8.2)$ \\
\hline September & 0 & $1(0.5)$ & $2(1.1)$ & $10(5.4)$ & $4(2.2)$ & $1(0.5)$ & $3(1.6)$ & $1(0.5)$ & $1(0.5)$ & $23(12.5)$ \\
\hline October & $3(1.6)$ & $2(1.1)$ & $4(2.2)$ & $4(2.2)$ & $2(1.1)$ & $1(0.5)$ & $3(1.6)$ & $1(0.5)$ & 0 & 20(10.9) \\
\hline November & 0 & $1(0.5)$ & $3(1.6)$ & 0 & $2(1.1)$ & $1(0.5)$ & $1(0.5)$ & $1(0.5)$ & $1(0.5)$ & $10(5.4)$ \\
\hline December & $3(1.6)$ & 0 & $3(1.6)$ & $1(0.5)$ & $1(0.5)$ & $1(0.5)$ & $2(1.1)$ & 0 & 0 & $11(6.0)$ \\
\hline January & 0 & $2(1.10$ & 0 & $2(1.1)$ & $1(0.5)$ & $1(0.5)$ & $4(2.2)$ & 0 & $2(1.1)$ & $12(6.5)$ \\
\hline February & $1(0.5)$ & 0 & $3(1.6)$ & $2(1.1)$ & $4(2.2)$ & 0 & $4(2.2)$ & $1(0.5)$ & 0 & $15(8.2)$ \\
\hline March & 0 & $3(1.6)$ & $2(1.1)$ & $4(2.2)$ & $3(1.6)$ & $4(2.2)$ & $3(1.6)$ & 0 & 0 & 19(10.3) \\
\hline April & $2(1.1)$ & $2(1.1)$ & 0 & $3(1.6)$ & $2(1.1)$ & 0 & $1(0.5)$ & $1(0.5)$ & $2(1.1)$ & $13(7.1)$ \\
\hline May & $1(0.5)$ & $3(1.6)$ & $1(0.5)$ & $1(0.5)$ & $3(1.6)$ & $3(1.6)$ & $1(0.5)$ & $2(1.1)$ & 0 & $15(8.2)$ \\
\hline Total & $12(6.5)$ & $20(10.9)$ & $22(12.0)$ & $32(17.4)$ & $36(19.6)$ & $21(11.4)$ & $24(13.0)$ & $10(5.4)$ & $7(3.8)$ & $184(100)$ \\
\hline
\end{tabular}

\begin{tabular}{|c|c|c|c|c|c|c|c|c|c|c|}
\hline Cause of death & $\begin{array}{l}<10 \\
N(\%)\end{array}$ & $\begin{array}{l}11-20 \\
N(\%)\end{array}$ & $\begin{array}{l}21-30 \\
N(\%)\end{array}$ & $\begin{array}{l}31-40 \\
N(\%)\end{array}$ & $\begin{array}{l}41-50 \\
N(\%)\end{array}$ & $\begin{array}{l}51-60 \\
N(\%)\end{array}$ & $\begin{array}{l}61-70 \\
N(\%)\end{array}$ & $\begin{array}{l}71-80 \\
N(\%)\end{array}$ & $\begin{array}{l}>81 \\
N(\%)\end{array}$ & $\begin{array}{l}\text { Total } \\
\mathbf{N}(\%)\end{array}$ \\
\hline Hanging & 0 & $12(6.5)$ & $5(2.7)$ & $6(3.3)$ & $7(3.8)$ & $4(2.2)$ & $5(2.7)$ & $2(1.1)$ & $2(1.1)$ & $43(23.4)$ \\
\hline Drowning & $1(0.5)$ & $1(0.5)$ & $3(1.6)$ & $4(2.2)$ & $3(1.6)$ & 0 & $2(1.1)$ & 0 & $1(0.5)$ & $15(8.2)$ \\
\hline Burn & $8(4.3)$ & $1(0.5)$ & $2(1.1)$ & $3(1.6)$ & $4(2.2)$ & $1(0.5)$ & $8(4.3)$ & $4(2.2)$ & $2(1.1)$ & $33(17.9)$ \\
\hline Injury (RTA) & $1(0.5)$ & $2(1.1)$ & $5(2.7)$ & $12(6.5)$ & $15(8.2)$ & $11(6.0)$ & $6(3.3)$ & $1(0.5)$ & 0 & $53(28.8)$ \\
\hline Injury (other than RTA) & $1(0.5)$ & $2(1.1)$ & $1(0.5)$ & $3(1.6)$ & $1(0.5)$ & $2(1.1)$ & $1(0.5)$ & 0 & $1(0.5)$ & $12(6.5)$ \\
\hline Electrocution & 0 & 0 & 0 & 0 & $1(0.5)$ & 0 & 0 & 0 & 0 & $1(0.5)$ \\
\hline Poisoning & 0 & $2(1.1)$ & $4(2.2)$ & $1(0.5)$ & $1(0.5)$ & $1(0.5)$ & 0 & 0 & 0 & $9(4.9)$ \\
\hline Undetermined & 0 & 0 & $1(0.5)$ & $1(0.5)$ & $4(2.2)$ & $2(1.1)$ & $2(1.1)$ & $3(1.6)$ & 0 & $13(7.1)$ \\
\hline Others & $1(0.5)$ & 0 & $1(0.5)$ & $2(1.1)$ & 0 & 0 & 0 & 0 & $1(0.5)$ & $5(2.7)$ \\
\hline Total & $12(6.5)$ & 20(10.9) & $22(12.0)$ & $32(17.4)$ & $36(19.6)$ & $21(11.4)$ & $24(13.0)$ & $10(5.4)$ & $07(3.8)$ & 184(100) \\
\hline
\end{tabular}

\section{DISCUSSION}

Accidents claim more lives in developing countries when compared with the developed countries. Road traffic accidents were the major cause of death in the present study. It was observed that 1,787 died due to RTAs in the 2070/71, 2,004 in 2071/72, 2,006 in 2072/73 and 2,384 in $2073 / 74$ across the country. ${ }^{5}$ Difficult geographical terrain, bad weather, bad roads, overloaded vehicles and high speed are some of the causes of RTAs in Nepal. Other causes of RTAs include prying stray animals and road encroachment by the street vendors and hawkers. ${ }^{6}$ Despite the rules and signs for traffic safety, most of the road users don't follow them. Driving under the influence of alcohol was a serious problem till 2011 AD when Nepal Police started "anti-drink and drive" campaign in December 2011 (2068 BS). As per the data provided by Nepal police, there were 315 casualties, 1333 seriously injured and 6886 minor injuries two years prior to the anti-drink and drive campaign. ${ }^{7}$ After two years of the drink and drive campaign the casualties were 297 , seriously injured were 524 and minor injuries were 6525 . There was overall decline in RTAs by $28 \%$, Injury decreased by $60 \%$ and fatalities decreased by $5 \%{ }^{7}$ Breath analyzers are used to determine blood alcohol level. Any driver driving vehicle under the influence of alcohol can be booked as per the existing law. Driving under influence of alcohol is prohibited as per the Article 142 of Motor Vehicles and Transport Management Act, 2049 (1993). ${ }^{8}$ As per the Articles 164 (j) and Article 170 of the same act, fine can be slammed ranging from Rupees 25 to 1000. It is a criminal offence to drive a public transport under the influence of alcohol. Stringent law is passed to punish the violators of traffic rules and safety, however, RTAs still remains a major cause of fatality in the region. Male preponderance was seen in fatal road accidents with a male to female ratio of $2.31: 1$, which is probably indicative of more males are driving the vehicle than the females. It is estimated that of all accidental fatalities globally, 25\% occur in South East Asian Region (SEAR). ${ }^{4,9-10}$

Fatal injuries sustained other than RTAs comprised of $6.5 \%$ 
of the total autopsy conducted in the present study. Those fatal injuries included injuries sustained as a result of fall from height, occupational injuries and animal attack. Intentional injuries are common in adolescent and young adults whereas accidental injuries are frequent in older adults. ${ }^{11}$

Injuries not only make victim suffer physically and psychologically, it has direct impact upon the victim's family too, who suffer from additional financial burden during treatment. Health and safety education in the form of booklets, pamphlets, advertisements in the media are to be undertaken because prevention is where all the efforts need to be aimed for.

Deaths due to hanging were the second leading cause of deaths after RTAs in the present study. Due to rapidity of fatality, it is one of the popular methods of committing suicide worldwide. ${ }^{12}$ Deaths due to hanging are considered suicidal until stated otherwise. ${ }^{12}$ Literatures suggest male preponderance in hanging which is also observed in the present study. ${ }^{13} \mathrm{~A}$ notable feature in the present study was hanging being more common in younger age group. This might be due to the reason that young people can't easily cope with stressful life events.

Mortality due to burn was also a major cause of unnatural death. As per the National population and housing census of 2011 issued by government of Nepal there are 59,260 households in Palpa district. ${ }^{14}$ Of the 59,260 houses only 8,950 have cement bonded bricks and stones in their outer walls. ${ }^{14}$ Electricity as a source of power is benefitted by 43,249 houses and rest rely upon kerosene, biogas and solar power for energy. ${ }^{14}$ It is also observed that 12,623 households have thatch or straw roofs. ${ }^{14}$ In Tansen Municipality of Palpa district, there are 8,433 households with a population of 31,161 of which 15,332 are males and 15,829 are females. ${ }^{14}$ Literatures suggest adult females and under five children are more vulnerable population to sustain burn injuries. ${ }^{4,15-17}$ Majority of the females are involved in cooking and meal preparation that might be the reason for increased burn related mortality in the present study. Most of the victims of burn injuries are designated accidental and cases of intentional burns go unreported. ${ }^{18}$ Literatures suggest that out of $50 \%$ of fire related deaths globally, two-third of world's female victims are from SEAR. ${ }^{9}$ Death of a female within 7 years of marriage is 'dowry death' and the perpetrators need to serve legal sentence for murder in India. ${ }^{4}$ Intentional burn in the form of dowry death is more common evil social practice in India; $;^{4,19}$ however, in Nepal the authors didn't come across such cases during the study period.

Studies regarding deaths due to drowning are sparse in Nepal. Study upon deliberate self-harm conducted in Western region of Nepal reported only a single case of drowning in between 2002 and 2005. ${ }^{20}$ Although there are media reports on deaths due to drowning, lack of study makes it a rarity. The present study conducted over a period of one year reports 15 cases of death due to drowning.
Although poisoning is one of the commonest methods of committing deliberate self-harm, advances in treatment of the victim with intensive care support might have declined the fatal outcome. A hospital based study of poisoning from eastern Nepal observed $17.6 \%$ mortality out of 85 cases of poisoning in two years. ${ }^{21} \mathrm{~A}$ descriptive epidemiological study on insecticide poisoning from central part of Nepal observed 439 cases of acute pesticide poisonings during a 9 month study of which $3.8 \%$ succumbed to death. ${ }^{22}$

The authors in the present study observed that $7.1 \%$ of total cases of unnatural deaths had no specific cause of deaths. When the cause of death could not be ascertained during post mortem examination, then such cases are obscure autopsy. In such cases investigation reports from forensic science laboratory (FSL) and histo-pathological examination of tissue samples aid to give a cause of death. Due to lack of FSL in the region, samples are sent to FSL in the capital. Samples obtained during autopsy for laboratory investigation are handed over to the investigation officer maintaining a chain of custody. Delayed dispatch of the sample would cause decomposition of the visceral tissue and/or drying of body fluids, ultimately leading to a negative autopsy. Wellequipped mortuary facility with facility for proper storage of collected biological samples till it is dispatched to FSL would prevent decomposition of such samples and help deduce obscure autopsies. The other reason for obscure autopsy might be due to the fact that most of the government hospitals, where autopsy is allowed lack forensic medicine experts. Autopsies in such hospitals are conducted by young medical graduates. Majority of the doctors who had been trained upon by autopsy surgeons after getting into government services, either don't implement the knowledge or are reluctant for complete autopsy due to their hectic clinical schedule. There are instances where young doctors recently recruited by the government conduct the autopsy based solely upon the knowledge they received during their forensic medicine classes as a medical undergraduates in medical school.

The present study didn't observe postmortem examination of the neonates. In cases of still birth or perinatal death autopsy is required to identify the cause of death. Without proper autopsy and placental histology, cause of death in cases of still birth or perinatal mortality is one of the modifiable risk factors. ${ }^{23}$

The recent Nepalese 'Criminal Procedural Act- 2074' clearly states the autopsy examination be conducted by Forensic Medicine experts in all possible cases. ${ }^{24} \mathrm{~A}$ uniform format is also issued to be used to report autopsy findings. But the investigating officers transfer the dead bodies to government hospitals where forensic experts are not available. When compared to the developed nation, Nepal still lacks uniform guidelines and protocols to handle medico-legal cases. Crime scene visit by Forensic Experts along with police for evidence collection would be vital in cases of homicide where the crime needs to be linked to the criminal. Inquest conducted by Medical examiner is considered superior than the police inquest by investigating officer. 
On a public health perspective, it is observed that accidents were the predominant cause of mortality. Vehicular accidents, accidental burn, accidental fall, accidental electrocution are all preventable. Stringent law after mishap is of least use as the victim is already suffering. Active involvement of law enforcing agencies (traffic police) for strict traffic rule compliance and driver safety is the need of time. The individual also needs to realize that accidents don't occur when they expect or the aftermath is a lesson to learn. Awareness campaigns for road safety are to be launched from central level. Prevention strategies like pavement of roads, instillation of traffic lights and signs, making of road bumps can be instigated from the central level. The young children should be taught about traffic rules and also hazards from fire and electricity in their classrooms so that when they grow adults they are already cautious.

\section{CONCLUSION}

Analysis of unnatural death of a community reflects the cause of death and socio-economic strata of that society. The present study reflected the spectrum of unnatural deaths in Palpa district of province 5, of Nepal which revealed RTA as a leading cause of death, followed by hanging. When gender was taken into account it was revealed that more females succumbed to death due to complications of the burn injuries sustained. Unnatural death due to fatal poisoning was least common finding of the present study although poisoning is one of the leading causes of deliberate self-harm globally. Proposal/program of collaboration of District Hospital with other tertiary care centres of Palpa district is the need of the hour which would provide specific, timely and expert approach to range of medico-legal cases. Lack of similar data from other districts

\section{REFERENCES}

1. Frentzel-Beyme R, Keil U, Pflanz M, Struba R, Wagner G. Mortality data and statistics, importance for health services and epidemiological research. MMW Munch Med Wochenschr. 1980;122(24):9016.PMID: 6771627.

2. Issa SY, El Dossary M, Salam MA, Al-Mazroua MK, Hamd MA, Kharoshah M. Spectrum of unnatural deaths associated with positive toxicology findings in Eastern province, KSA: An autopsy based study. Egyptian J Forensic Sci. 2016; 6:381-7.DOI: 10.1016/ j.ejfs.2016.05.005

3. Setel PW, Macfarlane SB, Szreter S, Mikkelsen L, Jha P, Stout S et al. A scandal of invisibility: making everyone count by counting everyone. Lancet. 2007;370(9598):1569-77.PMID: 17992727.

4. Kumar TS, KanchanT, Yoganarasimha K, Kumar GP.Profile of unnatural deathsin Manipal, Southern India1994-2004. J Clin Forensic Med. 2006;13(3):117-20. PMID: 16356752.

5. Over 2,000 people lose lives in road accidents annually. The Kathmandu Post; 2018 [cited 2019 May 2]. Available from: http:// bit.ly/2GTPeWT

6. Sharma BR Harish D, Sharma V, Vij K. Road Traffic Accidents- a demographic and topographic analysis; Med. Sci Law. 2001, 41:26674.PMID: 11506352.

7. Chand JB. Anti 'drink and drive' campaign in Nepal [cited 2019 May 2]. Available from: https://tinyurl.com/y2gqedoa was a drawback while comparing the trends of mortality from unnatural causes across the country. Until and unless a nation wise survey is done on the cause of unnatural deaths, government cannot formulate a clear cut action plan for preventable strategies.

\section{RECOMMENDATIONS}

The authors believe the findings of this study will provide a platform to formulate health related programs and policies for reducing unwanted mortalities. Collection and compilation of mortality audit data from all the institutions where autopsy is conducted across the country will serve for decision making and to save lives of citizens of Nepal.

\section{LIMITATION OF THE STUDY}

This study is limited to the unnatural deaths autopsied at district hospital, Palpa. Medico-legal autopsies are also done in Rampur Hospital in Palpa district. So, interpreting or generalizing the causes of unnatural deaths in Palpa district should be done cautiously.

\section{ACKNOWLEDGEMENTS}

The authors would like to thank Dr. Indira Devkota, Medical Officer, District Hospital Palpa for her support during data collection.

\section{CONFLICT OF INTEREST}

None declared.

\section{FINANCIAL DISCLOSURE}

None declared.

8. Motor Vehicles and Transport Management Act, 2049 (1993). [cited 2019 May 26]. Available from: https://tinyurl.com/y3bcgym 8

9. Park JE, Park K. Textbook of preventive and social medicine. 18th ed. Jabalpur, India: M/S Banarsi das Bhanot; 2005. p. 323-6.

10. SuriS, Parr M. The hidden epidemic-war on roads. Indian J Crit Care Med. 2004;8 (2):69-72. [cited 2019 March 3]. Available from: https:// tspace.library.utoronto.ca/bitstream/1807/4141/1/cm04014.pdf

11. Atreya A, Kanchan T, Karmacharya BG. Intentional Head Injury: Survivor Victim's Profile, Gender Differences and Role of Alcohol Use at Manipal Teaching Hospital, Pokhara, Nepal. Birat J Health Sci. 2017;2(1)2:102-5. DOI: https://doi.org/10.3126/bjhs.v2i1.17284.

12. Atreya A, Kanchan T. Clinico-epidemiological study of near-hanging cases- An investigation from Nepal. J Forensic Legal Med. 2015;33:35-8.PMID: 26048494.

13. Kanchan T, Menon A, Menezes RG. Methods of choice in completed suicides: Gender differences and review of literature. J Forensic Sci. 2009;54:938-42. PMID: 19486437.

14. National Population and Housing Census 2011 (National Report) [Internet]. Central bureau of statistics: Government of Nepal; 2012 [cited 2019 May 2]. Available from:https://unstats.un.org/ unsd/ demographic-social/census/documents/Nepal/Nepal-Census2011-Vol1.pdf

15. Karki B, Rai SM, Nakarmi KK, Basnet SJ, Magar MG, Nagarkoti KK, et al. Clinical Epidemiology of Acute Burn Injuries at Nepal Cleft and Burn Centre, Kathmandu, Nepal. Ann Plast Surg. 2018;80:S95-S97. PMID: 29319567. 
16. Gupta S, Mahmood U, Gurung S, Shrestha S, Kushner AL, Nwomeh $B C$ et al. Burns in Nepal: A population based national assessment. Burns.2015; 41:1126-32. PMID: 25523087.

17. Bailey ME, Sagiraju HKR, Mashreky SR, Alamgir H. Epidemiology and outcomes of burn injuries at a tertiary burn care center in Bangladesh. Burns. 2019; 45(4):957-63. PMID: 30612889.

18. Atreya A, Nepal S, Kanchan T. Intentional burns -A form of gender based violence in Nepal. Burns. 2016;42(3):712. PMID: 26777452.

19. Kumar V. Burnt wives - a study of suicides. Burns. 2003;29(1):31-5. PMID: 12543042

20. Subba SH, Binu VS, Menezes RG, Kanchan T, Arun M, Patil R, et al. Pattern and trends of deliberate self-harm in western Nepal. J Forensic Sci. 2009; 54(3):704-7. PMID: 19368624.
21. Rajbanshi LK, Arjyal B, Mandal R. Clinical Profile and Outcome of Patients with Acute Poisoning Admitted in Intensive Care Unit of Tertiary Care Center in Eastern Nepal. Indian J Crit Care Med. 2018;22(10):691-696. PMID: 30405278.

22. Gyenwali D, Vaidya A, Tiwari S, Khatiwada P, Lamsal DR, Giri S. Pesticide poisoning in Chitwan, Nepal: a descriptive epidemiological study. BMC Public Health. 2017;17(1):619. PMID: 28673345.

23. South Africa Every Death Counts Writing Group, Bradshaw D, Chopra M, Kerber K, Lawn JE, Bamford L, et al. Every death counts: use of mortality audit data for decision making to save the lives of mothers, babies, and children in South Africa. Lancet. 2008;371(9620):1294-304. PMID: 18406864.

24. Muluki Criminal Procedural Act, 2074. Government of Nepal [cited 2019 May 21]. Available from: http://www.lawcommission.gov.np/ 